\title{
Analisis Kemampuan Berpikir Kreatif Matematis Siswa pada Materi Peluang dengan Pendekatan Open-Ended Melalui Pembelajaran Daring
}

\author{
Dzulma Saddiati ${ }^{1}$, Ishaq Nuriadin ${ }^{2}$ \\ ${ }^{1,2}$ Program Studi Pendidikan Matematika, Fakultas Ilmu Pendidikan, Universitas Muhammadiyah Prof. Dr. HAMKA, \\ J1. Tanah Merdeka No 20, Kota Jakarta Timur, DKI Jakarta, Indonesia \\ dzulmasaddiati@gmail.com
}

\begin{abstract}
Entering the 21st century, students must have creative thinking skills to face various educational challenges which are certainly different. By increasing the ability to think creatively, a person can create or form new and unique ideas, from a good and right way of thinking. This study aims to analyze students' mathematical creative thinking skills with an open-ended approach through bold learning. Determining the subject using purposing sampling technique from 32 students consisting of 4 male students and 28 female students in class XI AKL 1 SMK Negeri 2 Cikarang Barat, West Java. The ability of the data collected from this research is research and interviews. Data analysis uses reduction, presentation and conclusion drawing. Based on the results of data analysis in the aspect of research and flexibility, each has a range of values, namely 51 with the creative category, the authenticity aspect of the value range of 24 with the uncreative category. The open-ended approach also affects students' mathematical creative thinking skills. Thus, mathematics teachers are advised to use an open-ended approach to develop students' creative thinking skills and student learning outcomes.
\end{abstract}

Keywords: mathematical creative thinking, open-ended approach

\begin{abstract}
Abstrak
Memasuki abad ke-21, kemampuan berpikir kreatif harus dimiliki siswa untuk menghadapi berbagai tantangan pendidikan yang tentunya berbeda-beda. Dengan meningkatkan kemampuan berpikir kreatif maka seseorang dapat membuat atau membentuk gagasan-gagasan yang baru dan unik, dari cara berpikir yang baik dan benar. Penelitian ini bertujuan untuk menganalisis kemampuan berpikir kreatif matematis siswa dengan pendekatan open-ended melalui pembelajaran daring. Menentukan subjek menggunakan teknik purposing sampling dari 32 siswa terdiri 4 siswa laki-laki dan 28 siswa peremuan kelas XI AKL 1 SMK Negeri 2 Cikarang Barat, Jawa Barat. Data kemampuan berpikir kreatif dikumpulkan menggunakan test uraian dan wawancara. Data dianalisis menggunakan reduksi, penyajian dan penarikan kesimpulan. Berdasarkan hasil analisis data dalam aspek kelancaran dan keluwesan memiliki rentang nilai masing-masing yaitu 51dengan kategori kreatif, aspek keaslian rentang nilai 24 dengan kategori tidak kreatif. Pendekatan open-ended juga mempengaruhi kemampuan berpikir kreatif matematis siswa. Dengan demikian guru matematika direkomendasikan untuk menggunakan pendekatan open-ended untuk mengembangkan kemampuan berpikir kreatif siswa serta hasil belajar siswa.
\end{abstract}

Kata kunci: berpikir kreatif matematis, pendekatan open-ended

Copyright (c) 2021 Dzulma Saddiati, Ishaq Nuriadin

$\triangle$ Corresponding author: Dzulma Saddiati

Email Address: dzulmasaddiati@gmail.com (Griya Asri 2 Jl. Kemuning 2 No 30 Bekasi Timur, Jawa Barat)

Received 16 Juni 2021, Accepted 21 Juni 2021, Published 24 Juni 2021

\section{PENDAHULUAN}

Memasuki abad ke-21, pendidikan di Indonesia dihadapi dengan berbagai tantangan yang tentunya berbeda dari sebelumnya. Pendidikan merupakan hal yang penting dalam kedidupan sehari-hari. Adanya pendidikan setiap generasi dapat menambah wawasan pengetahuan, keterampilan serta menumbuhan jati diri dan moral bangsa sebagai landasan hak dan kewajiban dalam negara. Kegiatan pendidikan berkaitan dengan tujuan pembelajaran yang mengacu pada kreatifitas, sesuai dengan Peraturan Pemerintah Nomor 17 Tahun 2010 dalam Kurikulum 2013 tentang Pengelolaan dan Penyelenggaraan Pendidikan, yang menyebutkan bahwa tujuan penyelenggaraan pendidikan menengah yaitu membenruk peserta didik menjadi insan berakhal mulia, kreatif, inovatif, percaya diri dan bertanggung jawab. Maka dapat disimpulkan bahwa, 
pendidikan dikembangkan untuk menghasilkan kemampuan kreatif serta keterampilan siswa. Hal tersebut dapat dicapai melalui proses yaitu ilmu pengatahun dan pengembangan teknologi.

Mengenai perkembangan teknologi, teknologi saat ini memudahkan seseorang terhubung secara online, seperti media sosial yang dapat diakses dengan mudah dan cepat. Salah satunya di era digital sangat berpengaruh terhadap sistem pembelajaran yang ada pada saat ini, ditunjukkan dengan adanya wabah COVID-19, dimana siswa serta guru harus melakukan proses pembelajaran maupun kegiatan lainnya di rumah dengan metode dalam jaringan (daring). Berbeda dengan sistem sebelumnya dimana siswa dan guru bertemu secara langsung.

Pada matematika, pentingnya mengembangkan kemampuan berpikir kreatif terdapat pada tujuan Permendikbud No. 59 tahun 2014 tentang Kurikulum Matematika SMA yang menyatakan bahwa peserta ditekankan pada berpikir logis dan kreatif bukan hanya sekedar berpikir mekanistis. Dalam tujuan tersebut menyebutkan bahwa salah satu kriteria mengenai kualifikasi kemampuan lulusan yang harus dimiliki oleh siswa dalam pembelajaran matematika yaitu memiliki kemampuan berpikir kreatif. Oleh karena itu, kemampuan berpikir kreatif matematis siswa dapat dikembangkan atau ditingkatkan berdasarkan aspek berpikir kreatif menurut Anwar.

Anwar (Mursidik et al., 2015) mengatakan bahwa dalam kemampuan berpikir kreatif terdapat empat aspek yaitu fluency (kefasihan), flexybility (keluwesan), originality (keaslian), dan elaboration (keterincian). Fluency mengacu pada mengacu pada kemampuan siswa menjawab masalah dengan lancar dan benar, flexibility mengacu pada kemampuan siswa menggunakan banyak cara dalam menjawab soal, originality mengacu pada kemampuan siswa menjawab soal yang berbeda dengan siswa lain dan baru, dan elaboration mengacu pada kemampuan siswa untuk menjelaskan secara runtut, rinci dan saling terkait antara satu langkah dengan langkah yang lain.

Berdasarkan pengalaman peneliti saat magang 3 di kelas XI OTKP 1 SMKN 22 Jakarta, peneliti menanyakan ke beberapa siswa perihal pembelajaran matematika selama dikelas. Beberapa siswa mengatakan mengalami kesulitan dalam pembelajaran matematika, menurutnya pembelajaran matematika selalu hitung-hitungan, siswa lain juga mengatakan jika ia tidak memahami materi yang diajarkan. Terutama materi peluang kejadian, sebab siswa harus memahai konsep dasar dari peluang kejadian seperti aturan perkalian, kombinasi, permutasi sebelum nantinya akan memasuki materi peluang kejadian. Strategi yang memungkinkan untuk mendorong daya berpikir siswa yang lebih aktif, kreatif dan mempunyai berbagai penyelesaian yaitu pendekatan open-ended.

Pendekatan open-ended adalah suatu pendekatan pembelajaran dimulai dengan pemberian masalah terbuka sehingga peserta didik dapat menjawab dengan banyak cara dan kemungkinan banyaknya jawaban benar (Anwar et al., 2015). Sejalan dengan Nohda (Firdaus et al., 2016) mengatakan tujuan pembelajaran dengan pendekatan open-ended adalah untuk membantu mengembangkan aktivitas yang kreatif dari siswa dan kemampuan berpikir matematis mereka dalam memecahkan masalah. Selain itu, dengan pendekatan ini diharapkan dapat meningkatkan kualitas pembelajaran. 
Dalam penelitian ini, untuk mengetahui kemampuan berpikir kreatif matematis siswa melalui pendekatan open-ended dengan menyelesaikan masalah terbuka pada materi peluang. Menyelesaikan soal peluang diperlukan tahap berpikir kreatif matematis. Sesuai dengan pernyataan Mihajlovic dan Dejic (Muslimatus Nudiyah, 2017) bahwa salah satu keuntungan penggunaan masalah open-ended ialah mengembangkan berpikir kreatif siswa. Diharapkan guru matematika dalam melaksanakan pembelajaran menggunakan pendekatan open-ended, dapat meningkatkan kemampuan siswa dalam memecahkan masalah dengan ide yang berbeda-beda berdasarkan kemampuan yang dimilikinya.

Berdasarkan uraian di atas, peniliti merasa tertarik untuk mendeskripsikan hasil aspek kefasihan, keluwesan dan keaslian siswa melalui pendekatan open-ended melalui pembelajaran daring.

\section{METODE}

Penelitian ini menggunakan pendekatan kualitatif dengan metode deskriptif. Menurut Dezin dan Lincoln (Anggito, A \& Setiawan, J., 2018) mengartikan bahwa penelitian kualitatif yaitu penelitian yang menggunakan latar alamiah dengan maksud menafsirkan fenomena yang terjadi dan dilakukan dengan jalan melibatkan berbagai metode yang ada. Lokasi penelitian di SMK Negeri 2 Cikarang Barat, Jawa Barat. Penelitian ini dilaksanakan di kelas XI SMK pada tahun ajaran 2020/2021. Subjek dalam penelitian ini adalah siswa kelas XI Akutansi dan Keuangan Lembaga (AKL) 1 berjumlah 32 siswa terdiri 4 siswa lakilaki dan 28 siswa perempuan. Subjek dipili berdasarkan

Subjek dipilih berdasarkan rata-rata nilai dari test yang berupa soal uraian sebanyak 5 soal dengan tipe soal terbuka. Setelah subjek ditentukan maka dilakukan wawancara untuk mengetahui bagaimana proses penyelesaian. Penelitian ini menggunakan indikator kemampuan berpikir kreatif dari (Siswono, 2016) yaitu (1) Kefasihan, (2) Keluwesan, dan (3) Keaslian.

Tabel. 1 Indikator Kemampuan Berpikir Kreatif

\begin{tabular}{|c|l|}
\hline Aspek Berpikir Kreatif & \multicolumn{1}{c|}{ Indikator } \\
\hline Kefasihan & $\begin{array}{l}\text { Kemampuan siswa menghasilkan banyak jawaban/gagasan } \\
\text { pemecahan masalah secara lancar dan tepat. }\end{array}$ \\
\hline Keluwesan & $\begin{array}{l}\text { Kemampuan siswa menyajikan sejumlah cara yang berbeda } \\
\text { untuk menyelesaikan masalah. }\end{array}$ \\
\hline Keaslian & $\begin{array}{l}\text { Berkaitan dengan kemampuan siswa menghasilkan cara } \\
\text { baru/unik dari pemikiran yang telah ada. }\end{array}$ \\
\hline
\end{tabular}

Langkah-langkah penelitian ini, yaitu (1) Guru memberikan pembelajaran materi peluang dengan pendekatan open-ended, (2) Mengumpulkan nilai test uraian, (3) Mencari rata-rata nilai dari test uraian, (4) Pemilihan subjek penelitian didasarkan pada hasil pengelompokan kemampuan berpikir kreatif matematis, (4) Peniliti melakukan wawancara sesuai dengan subjek yang dipilih, (5) menarik kesimpulan. 
Instrumen penelitian berupa kisi-kisi tes, soal tes, alternatif penyelesaian, pedoman penskoran dan pedoman wawancara yang telah divalidasi oleh satu orang dosen Pendidikan Matematika FKIP UHAMKA dan satu guru Matematika SMK Negeri 22 Jakarta. Teknik analisis data pada penelitian ini meliputi 3 tahap antara lain: (1) reduksi data melalui test dan wawancara, proses ini memisahkan antara data yang sesuai dan tidak sesuai terkait kemampuan berpikir kreatif, (2) penyajian data yaitu meliputi kegiatan pengklasifikasian dan mendeskripsikan berdasarkan tiga kriteria kemampuan berpikir kreatif yaitu kefasihan, keluwesan dan keaslian, serta (3) penarikan kesimpulan tentang kemampuan berpikir kreatif matematis siswa. Reduksi data dilakukan untuk mempermudah peneliti dalam memilih data yang sesuai. Penyajian data dilakukan agar data yang disajikan lebih mudah dipahami. Setelah itu dilakukan penarikan kesimpulan tentang kemampuan berpikir kreatif matematis siswa dengan pendekatan open-ended melalui pembelajaran daring.

\section{HASIL DAN DISKUSI}

Hasil penelitian ini data hasil penyelesaian siswa berupa instrument soal tes uraian sebanyak 5 soal. Hasil jawaban siswa kelas XI AKL 1 di SMK Negeri 2 Cikarang Barat digunakan sebagai data, seperti tabel dibawah ini.

Tabel 2. Aspek Kefasihan

\begin{tabular}{|c|c|c|c|c|c|c|}
\hline \multirow{2}{*}{ Kode Siswa } & \multicolumn{5}{|c|}{ Skor tiap butir soal } & \multirow{2}{*}{ Skor Total (Y) } \\
\cline { 2 - 6 } & $\mathrm{x} 1$ & $\mathrm{x} 2$ & $\mathrm{x} 3$ & $\mathrm{x} 4$ & $\mathrm{x} 5$ & \\
\hline Rata-rata & 0,99 & 0,82 & 0,63 & 0,88 & 0,75 & \multirow{2}{*}{51} \\
\hline Rentang & 63 & 52 & 40 & 56 & 48 & \\
\hline
\end{tabular}

Pada Tabel 2 aspek kefasihan di atas memiliki rentang nilai 49 dengan kategori yaitu kreatif.

Tabel 3. Aspek Keluwesan

\begin{tabular}{|c|c|c|c|c|c|}
\hline \multirow{2}{*}{ Kode Siswa } & \multicolumn{4}{|c|}{ Skor tiap butir soal } & Skor Total (Y) \\
\cline { 2 - 5 } & $\mathrm{x} 1$ & $\mathrm{x} 2$ & $\mathrm{x} 3$ & $\mathrm{x} 5$ & \multirow{2}{*}{51} \\
\hline Rata-rata & 0,96 & 0,87 & 0,81 & 0,58 & \multirow{2}{*}{51} \\
\hline Rentang & 62 & 56 & 52 & 37 & \\
\hline
\end{tabular}

Pada Tabel 3 indikator keluwesan di atas memiliki rentang nilai 52 dengan kategori yaitu kreatif.

Tabel 4. Aspek Keaslian

\begin{tabular}{|c|c|c|c|}
\hline \multirow{2}{*}{ Kode Siswa } & \multicolumn{2}{|c|}{$\begin{array}{c}\text { Skor tiap butir } \\
\text { soal }\end{array}$} & Skor Total (Y) \\
\cline { 2 - 3 } & $\mathrm{x} 2$ & $\mathrm{x} 4$ & \multirow{2}{*}{2} \\
\hline Rata-rata & 0,53 & 0,24 & \multirow{2}{*}{24} \\
\hline Rentang & 34 & 15 & \\
\hline
\end{tabular}

Pada Tabel 5 indikator keaslian di atas memiliki rentang nilai 24 dengan kategori tidak kreatif. 
Melihat hasil rentang nilai dari seluruh aspek kemampuan berpikir kreatif matematis dengan jumlah 32 siswa, dapat dilihat bahwa aspek tertinggi yaitu aspek kefasihan dengan rentang nilai 49 sedangkan terendah aspek keaslian dengan nilai rentang 25 .

\section{Aspek Kefasihan}

Pada aspek kefasihan ditemukan 1 siswa yang menyelesaikan hanya 1 jawaban saja, seperti gambar di bawah ini

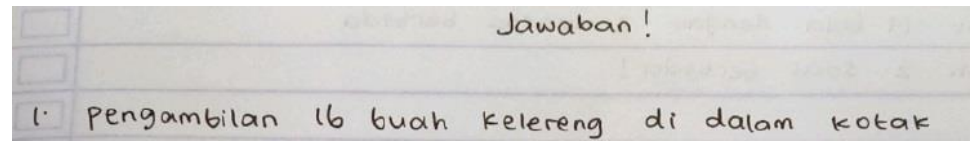

Gambar 1. Jawaban Subjek AS

Gambar di atas menunjukkan hasil jawaban siswa AS, ia hanya mampu menjawab 1 jawaban, sedangkan jawaban yang diminta dua atau lebih percobaan yang menghasilkan ruang sample 16. Berdasarkan hasil wawancara, AS menjelaskan bahwa ia memahami soal yang diberikan, namun ia hanya terbesit 1 percobaan yaitu pada kelereng. Jika dibandingkan dengan jawaban yang sebenernya sangat berbeda jauh dilihat dari Gambar 2.

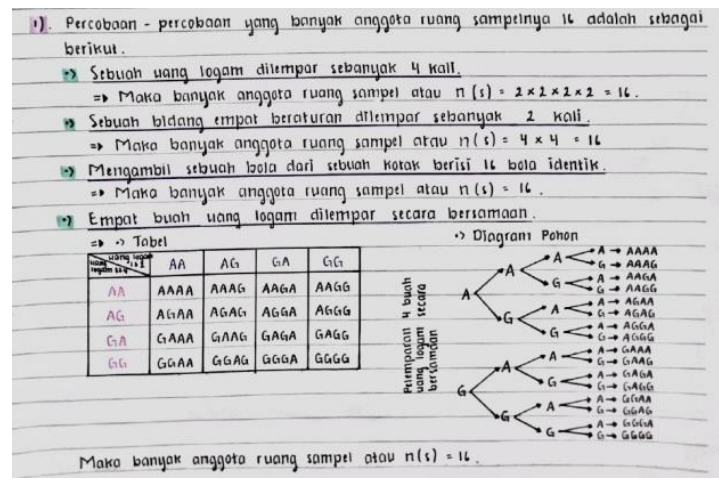

\section{Gambar 2. Jawaban Subjek AY}

Adapula 2 siswa yang terdapat kekeliuran angka pada soal nomor 2 saat pengerjaannya tampak pada Gambar 3.

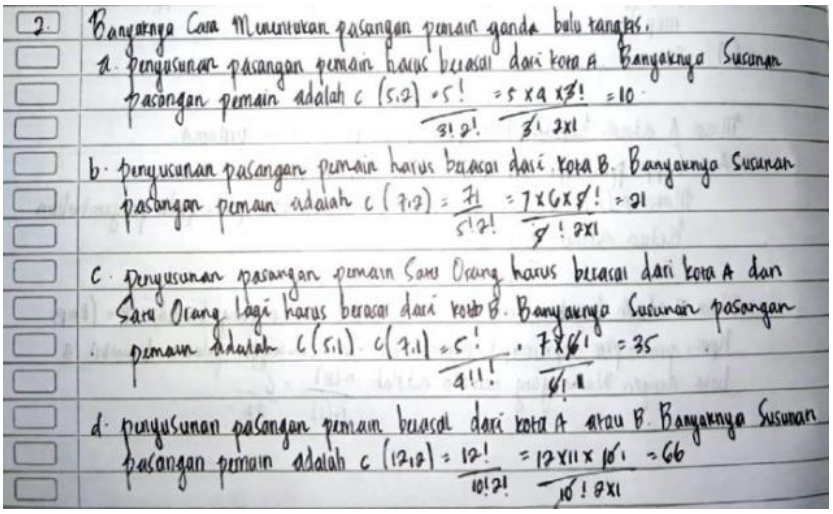

Gambar 3. Jawaban Subjek AP 
Gambar 3 merupakan jawaban siswa AP, ia keliru dalam angka pengerjaan sama halnya dengan AS. Soal yang diketahui yaitu 5 pemain dari kota A dan 3 pemain dari kota $\mathrm{B}$, tetapi AP menyelesaikan dari kota B dengan 7 pemain, sehingga jawabannya salah meskipun cara pengerjaannya sudah benar. Siswa AP dan AS juga salah dalam menuliskan soal nomor 3, seperti gambar di bawah ini.

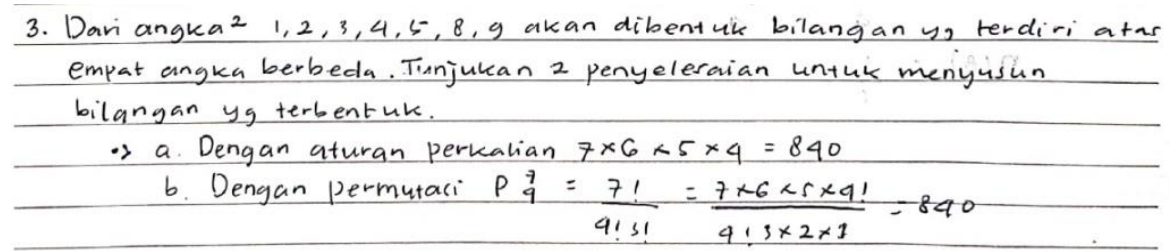

Gambar 4. Jawaban Subjek AS

Gambar di atas adalah jawaban dari AS, dimana ia menuliskan soal yang serupa seperti soal yang diberikan untuk penelitian. Soal yang dijadikan penelitian memberikan pernyataan bahwa terdapat 6 angka yaitu 1, 3, 5, 7, 9. Sehingga jawaban AP dan AS tidak terdapat nilai meski cara pengerjaannya sudah benar. Berdasarkan hasil wawancara AP dan AS memiliki penjelasan yang sama. AP menejelaskan "saya tidak fokus bu kalau angkanya ternyata beda, karena soal yang saya cari mirip jadi saya malah kerjakan dengan angka yang di internet". Keterangan AP sejalan dengan hasil penelitian (Widiastuti \& Putri, 2018) siswa dengan kategori kemampuan berpikir kreatif rendah tidak berusaha untuk memahami soal tersebut dan selalu ketergantungan dengan soal yang rutin sehingga jawabannya menjadi kurang tepat. AP dan AS juga menjelaskan dalam mengerjakan soal mereka ketergantungan dengan catatan guru maupun dari internet.

\section{Aspek Keluwesan}

Pada aspek keluwesan terdapat 3 siswa memberikan 1 cara saja pada pengerjaannya, seperti gambar di bawan ini.

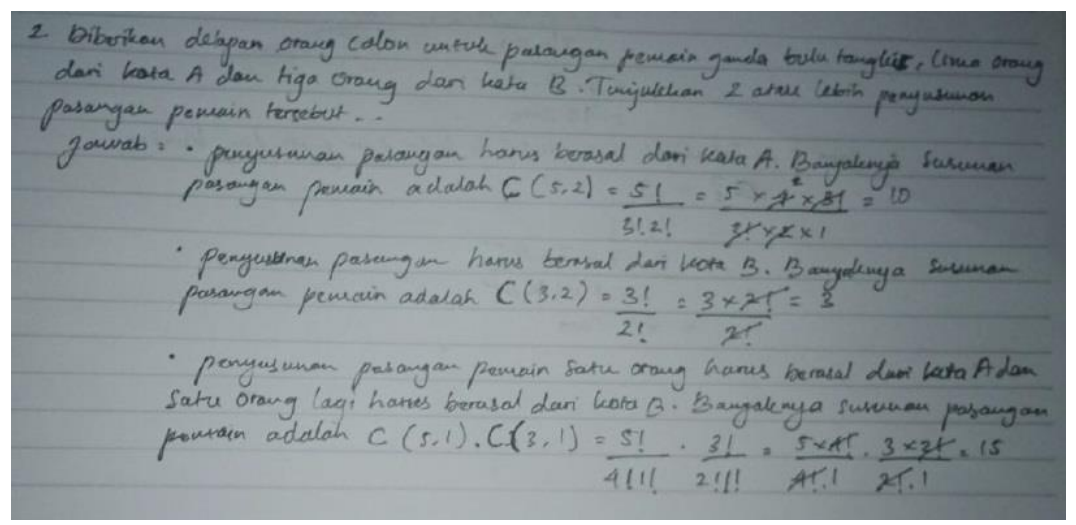

Gambar 5. Jawaban Subjek MNH

MNH hanya memberikan 1 cara saja yaitu dengan menentukan pasangan pemain badminton dari masing-masing Kota A dan Kota B serta pasangan dari kedua kota tersebut. Cara lainnya yaitu dengan menentukan pasangan jika dinyatakan pemain dari Kota A atau B seperti tampak pada Gambar 6. 


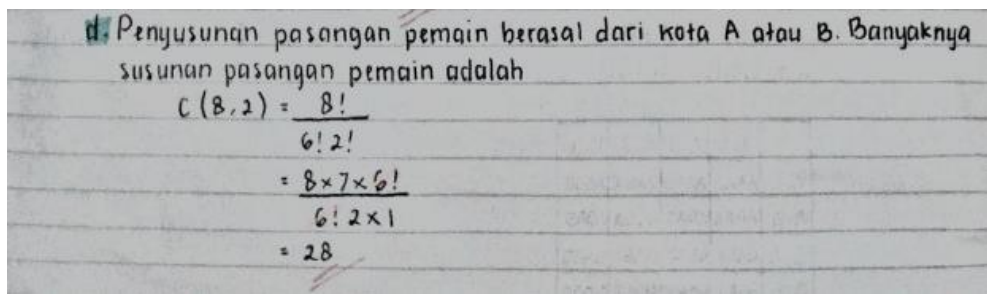

Gambar 6. Jawaban Subjek AY

Berdasarkan hasil wawancara MFH menjelaskan seperti pada kutipan berikut "saya cuman kepikiran satu cara aja sih bu, saya nggak tau kalau mau kerjain cara lain kaya gimana". Hasil wawancara MFH sejalan dengan hasil penelitian (Mursidik et al., 2015) siswa dengan kategori kemampuan berpikir kreatif sedang dalam memunculkan satu ide dalam menyelesaikan masalah open-ended masuk dalam kategori baik dan tidak mengalami kesulitan.

\section{Aspek Keaslian}

Pada indikator Keaslian hanya ada 1 siswa yang memberikan jawaban berbeda dari siswa lainnya, dilihat pada Gambar 7.

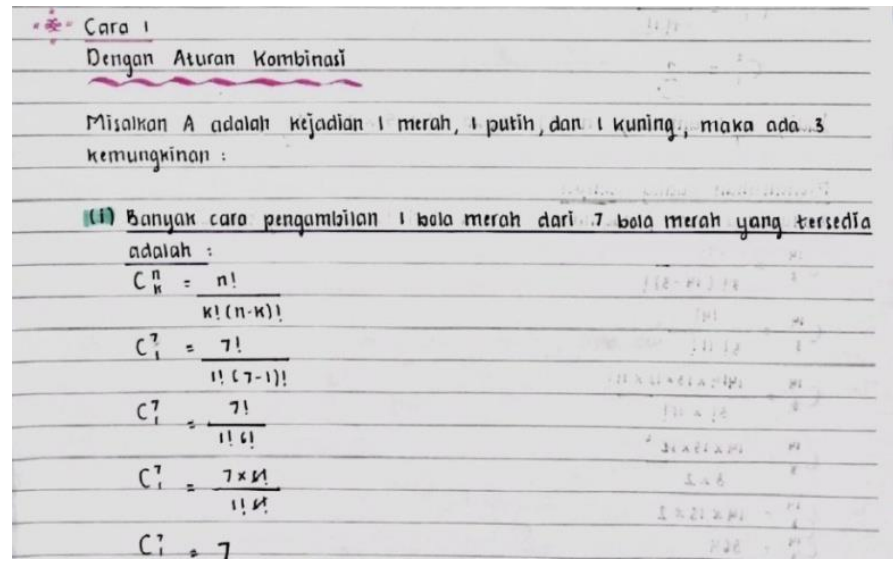

Gambar 7. Jawaban Subjek AY cara pertama

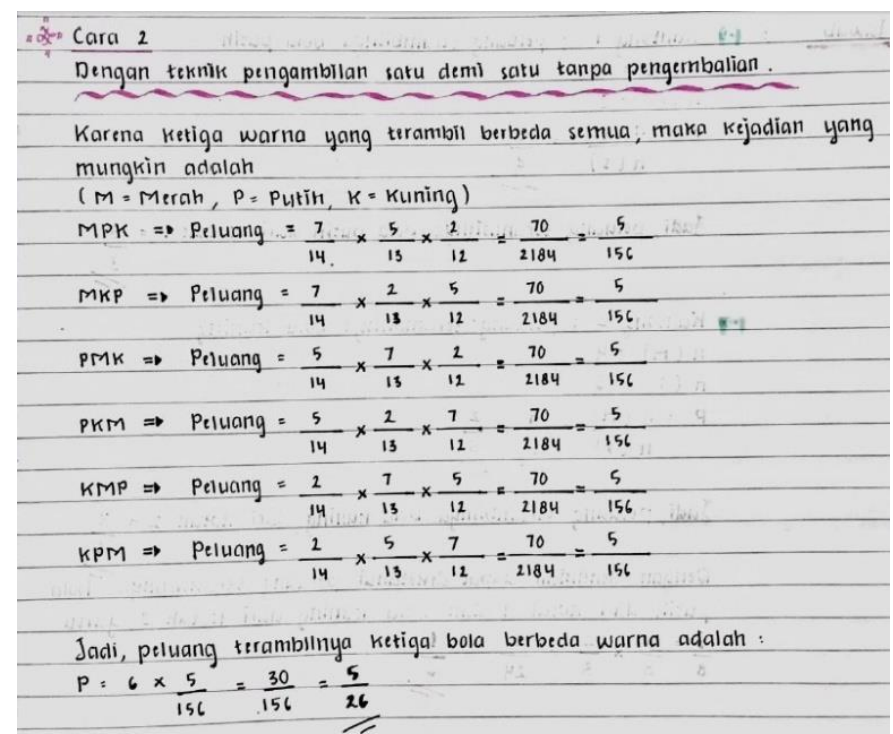

Gambar 8. Jawaban Subjek AY cara kedua 
Gambar 7 dan 8 adalah jawaban dari siswa AY. Soal nomor 5 memang berkaitan dengan nomor 4, dimana soal nomor 4 siswa harus membuat soal dari pernyataan yang diberikan. Meskipun pada soal no 4 AY memberikan jawaban atau membuat pertanyaan yang sama seperti siswa lainnya, namun dalam menjawab pertanyaan yang dibuatnya sangat berbeda jauh dari siswa lainnya. Berdasarkan hasil wawancara AY menjelaskan "pas liat nomor 4 saya paling lama karena harus buat soal kan bu dan soal itu jugga harus punya dua cara penyelesaian, setelah saya buat soalnya pas mengerjakan nomor 5 saya tidak ada kesulitan karean saya sudah tau soal yang saya buat nantinya jawabannya ada dua cara dan tau perhitungganta bagaimana". Pernyataan AY sejalan dengan penelitian (Rizqi et al., 2016) yakni siswa dengan kepercayaan diri tinggi mampu mengungkapkan ide-ide matematis melalui lisan dan tulisan, menggambarkan ide-ide matematis dalam bentuk visual, dan menggunakan notasi dan istilah matematis untuk menyajikan ide-ide matematis dengan baik.

Satu minggu sebelum penelitian, peneliti dengan guru yang mengajar di kelas XI AKL 1 mendiskusikan bagaimana langkah-langkah pendekatan tersebut dengan pembelajaran daring. Pelaksanaannya dilakukan dalam dua hari, pada hari pertama guru memberikan materi dengan pendekatan open-ended melalui whatsapp grup serta e-learning sekolah dan hari kedua guru memberikan soal uraian yang mana menjadi instrument penelitian. Saat memberikan pembelajaran dengan open-ended terdapat dua langkah yang guru tidak dapat laksanakan yaitu diskusi berkelompok serta mempresentasikan hasil diskusinya hal ini karena beberapa siswa masih melaksanakan praktek kerja lapangan (PKL) sehingga guru memberikan materi dalam bentuk video pembelajaran yang berisi penyajian masalah terbuka dan memberikanan pertanyaan atau soal-soal terbuka.

Meskipun dalam pelaksanaan pendekatan open-ended terdapat langkah yang tidak terlaksana, guru serta peneliti membuat rencana dimana saat langkah siswa mengerjakan soal secara individu peneliti membuat 5 soal dalam bentuk terbuka. Berdasarkan hasil analisis penelitian, maka presentase kemampuan berpikir kreatif siswa kelas XI AKL 1 dengan pendekatan open-ended dapat dilihat pada tabel di bawah ini.

Tabel 5. Kategori Kemampuan Berpikir Kreatis Matematis

\begin{tabular}{|c|c|c|}
\hline Kategori & Jumlah & Presentase \\
\hline Sangat Tidak Kreatif & 2 & $6,25 \%$ \\
\hline Tidak Kreatif & 3 & $9,375 \%$ \\
\hline Cukup Kreatif & 3 & $9,375 \%$ \\
\hline Kreatif & 12 & $37,5 \%$ \\
\hline Sangat Kreatif & 12 & $37,5 \%$ \\
\hline
\end{tabular}

Berdasarkan pada tabel di atas presentase keberhasilan pendekatan open-ended pada pembelajaran sebesar 84,375 \% dengan kategori kreatif, hal ini didukung dengan hasil penelitian (Firdaus et al., 2016) yang menyimpulkan bahwa pendekatan open-ended dapat meningkatkan kemampuan berpikir kreatif yang mempunyai siswa berada pada kriteria minimal cukup kreatif. Maka sesuai dengan pendapat (Mursidik et al., 2015) pendekatan open-ended adalah suatu pendekatan pemecahan masalah yang dapat mendorong kreativitas dan inovasi berpikir matematika siswa secara lebih bervariasi. 
Berdasarkan hasil penelitian tiap subjek dalam berproses berpikir kreatif siswa dalam menyelesaikan soal berbeda-beda, hal ini sesuai dengan (Utami et al., 2020) bahwa siswa dalam melibatkan sitesis ide-ide, membangun ide-ide baru dan menentukan efektivitasnya menunjukan ciri-ciri yang berbeda tiap kategorinya. Sejalan dengan penelitian (Muslimatus Nudiyah, 2017) menyatakan kategori jawaban kemampuan berpikir kreatif siswa tiap aspek bervariasi. Dari kelima soal yang dikerjakan, soal yang paling sulit menurut siswa yaitu soal nomor 4, karena siswa harus membuat soal dengan hasil penyelesaian memberikan banyak cara dan jawaban, hal ini sesuai dengan (Siswono, 2016) kemampuan berpikir kreatif matematis memiliki 3 komponen yaitu kelancaran, keluwesan dan keaslian.

\section{KESIMPULAN}

Kemampuan berpikir kreattif matematis siswa pada materi peluang dengan pendekatan open-ended melalui pembelajaran daring dapat disimpulkan, AP dan AS adalah siswa dengan kategori sangat tidak kreatif dan tidak kreatif, dimana rentang nilai dalam indikator kemampuan berpikir kreatif matematis sangat rendah dalam menyelesaikan test yang diberikan, hanya ada 1 soal yang benar saja, selebihnya terdapat kekeliuran angka serta tidak paham dengan pengerjaanya. AST dan MNH adalah siswa dengan kategori cukup kreatif dan kreatif, dimana rentang nilai dalam indikator kemampuan berpikir kreatif cukup baik dalam menyelesaikan test yang diberikan, hanya beberapa soal AST terdapat kekeliuran angka dalam pengerjaan test dan memberikan satu jawaban dan satu cara, MNH hanya memberikan satu cara di beberapa soal yang diberikan. Kemudian AY adalah siswa dengan kategori sangat kreatif, dimana rentang nilai dalam indikator kemampuan berpikir kreatif matematis sangat tinggi dalam menyelesaikan test yang diberikan, setiap soal AY memberikan jawaban lebih dari satu jawaban serta memiliki dua cara penyelesaian. Pendekatan open-ended juga mempengaruhi kemampuan berpikir kreatif matematis siswa. Dengan demikian guru matematika direkomendasikan untuk menggunakan pendekatan open-ended untuk mengembangkan kemampuan berpikir kreatif siswa serta hasil belajar siswa.

\section{UCAPAN TERIMA KASIH}

Pertama-tama saya ucapkan tiada hentinya kepada Allah SWT yang telah memberikan kelancaran saya dalam menyusun artikel, kedua saya ucapkan terimakasih kepada orang tua dan keluarga yang tiada hentinya mendoakan saya dan mendukung dalam menyusu artikel ini hingga selesai. Kemudian saya berterimakasih kepada Bapak Ishaq Nuriadin selaku dosen pembimbing saya yang senantiasa selalu memberikan arahan selama proses penilitian hingga proses penyusunan, dan saya berterimakasih kepada teman-teman seperjuangan saya yang selalu mendoakan serta membantu dan memberikan semangat kepada saya selama penyusunan artikel ini. Serta berterimakasih kepada sekolah SMK Negeri 2 Cikarang Barat yang telah mengizinkan saya untuk melaksanakan penelitian.

\section{REFERENSI}

Anggito, A., \& Setiawan, J. (2018). Metodologi penelitian kualitatif. CV Jejak (Jejak Publisher). 
Anwar, N., Johar, R., \& Juandi, D. (2015). Pengembangan Lks Berbasis Pendekatan Open-Ended Untuk Meningkatkan Kemampuan Berpikir Kreatif Matematis Siswa. Prima: Jurnal Pendidikan Matematika, 2(1), 52-63. https://doi.org/10.31000/prima.v3i1.814

Firdaus, As'ari, A. R., \& Qohar, A. (2016). Meningkatkan Kemampuan Berpikir Kreatif Matematis Siswa SMA Melalui Pembelajaran Open-Ended Pada Materi SPLTV. Jurnal Pendidikan, 1(2), 227-236. https://doi.org/10.20956/jmsk.v15i2.5719

Mursidik, E. M., Samsiyah, N., \& Rudyanto, H. erik. (2015). Kemampuan Berpikir Kreatif dalam Memecahkan Masalah Matematika Open-Ended Ditinjau dari Tingkat Kemampuan Matematika Pada Siswa Sekolah Dasar. Journal Pendagogia, 4(1), 23-33. https://doi.org/https://doi.org/10.21070/pedagogia.v4i1.69

Muslimatus Nudiyah, N. (2017). Proses Berpikir Kreatif Siswa Sma Dalam Memecahkan Masalah Matematika Openended Ditinjau Dari Kemampuan Matematika. MATHEdunesa, 6(2), 49-56. https://jurnalmahasiswa.unesa.ac.id/index.php/mathedunesa/article/view/19731/18045

Peraturan Pemerintah Nomor 17 tentang Pengelolaan dan Penyelenggaraan Pendidikan dalam Kurikulum 2013. (2010). Jakarta: BPK RI. Diambil dari https://peraturan.bpk.go.id/Home/Details/5025/pp-no17-tahun-2010

Permendikbud No. 59 tentang Kurikulum Matematika SMA. (2014). Jakarta: Kemendikbud

Rizqi, A. A., Hardi, S., \& Sudarmin. (2016). Analisis Kemampuan Komunikasi Matematis Ditinjau Dari Kepercayaan Diri Siswa Melalui Blended Learning. Unnes Journal of Mathematics Education Research, 5(1), 17-23. https://journal.unnes.ac.id/sju/index.php/ujmer/article/view/12911

Siswono, T. Y. (2016). Proses Berpikir Kreatif Siswa Dalam Memecahkan dan Mengajukan Masalah $\begin{array}{llll}\text { Matematika. Jurnal } & \text { Ilmu }\end{array}$ https://doi.org/http://dx.doi.org/10.17977/jip.v15i1.13

Utami, R. W., Endaryono, B. T., \& Djuhartono, T. (2020). Meningkatkan Kemampuan Berpikir Kreatif. $\begin{array}{llll}\text { Jurnal } & \text { Ilmiah } & \text { Kependidikan, } & \text { 43-48, }\end{array}$ https://journal.lppmunindra.ac.id/index.php/Faktor/article/view/5328/2997

Widiastuti, Y., \& Putri, R. I. I. (2018). Kemampuan Berpikir Kreatif Siswa pada Pembelajaran Operasi Pecahan Menggunakan Pendekatan Open-Ended. Jurnal Pendidikan Matematika, 12(2), 13-22. https://ejournal.unsri.ac.id/index.php/jpm/article/view/5961/0 